Káñina, Rev. Artes y Letras, Univ. Costa Rica XL(2) (julio-diciembre): 55-71, 2016/ ISSN:2215-2636

\title{
EL BESTIARIO EN LA LITERATURA DE CLAUDIA HERNANDEZ: UNA REPRESENTACIÓN DE SUBJETIVIDADES EN LA LITERATURA POSGUERRA
}

The bestiary of Claudia Hernandez: a representation of subjectivities in postwar literature **

\section{Hilda Gairaud Ruiz*}

\begin{abstract}
RESUMEN
El objetivo del presente ensayo es examinar algunos relatos de la autora salvadoreña Claudia Hernández dentro de la categoría de la literatura de posguerra. La designación de bestiario en la narrativa surge de la asociación que se hace de la representación simbólica de animales a personajes que integran diversos grupos sociales si se correlacionan con la historia salvadoreña, especialmente el período de la guerra y la posguerra. La intencionalidad discursiva de representar personajes como bestias es la de evidenciar la violencia y la degradación que han caracterizado la condición existencial de algunos tipos de subjetividades en la historia de El Salvador.
\end{abstract}

Palabras clave: bestiario, subjetividad, violencia, opresión, subalternidad.

\begin{abstract}
The main objective of this essay is to examine diverse short stories written by the Salvadorian author Claudia Hernández within the category of the postwar literature. The name of bestiary in the narration emerges from the association of the symbolic representation of animals to characters that integrate diverse social groups, if one correlates the history of El Salvador specifically during the war and the postwar period with the stories. The discursive intention of representing characters as beasts is to evidence the violence and degradation that have characterized the existential condition of some types of subjectivities in the history of this Central American country.
\end{abstract}

Key Words: bestiary, subjectivity, violence, oppression, subaltern.

\footnotetext{
* Universidad de Costa Rica. Profesora asociada de la Escuela de Lenguas Modernas. Costa Rica. Correo electrónico: hgairaud@yahoo.com

** Traducción hecha por la autora.

Recepción: 16/02/15. Aceptación: 20/10/15.
} 


\section{Introducción}

La producciones literarias centroamericanas de posguerra incluyen autores como Manlio Argueta, Claudia Hernández, Horacio Moya Castellanos y Franz Galich. El corpus literario asociado a estos autores centroamericanos presenta, en algunos de sus textos, ciertas temáticas y estrategias literarias asociadas a una estética vinculada a las representaciones de la violencia producida por la guerra civil al inicio de la década de los ochenta del siglo veinte. Esta estética origina que estos textos se ubiquen dentro de una categorización dentro de la literatura regional llamada literatura de posguerra. La literatura de estos escritores promovió la representación y reconocimiento de subjetividades marginalizadas y excluidas y, además, proveyó espacios para denunciar y visibilizar la violencia de la cual han sido víctimas.

En el presente artículo voy a referirme a la narrativa de Claudia Hernández quien desarrolla temáticas vinculadas a la representación discursiva de la diferencia, la exclusión, la marginalización. Sus personajes muestran el drama de vivir expuestos a la violencia, ya que la violencia que se representa en sus cuentos contiene algunos referentes extra literarios entrecruzados con la historia de la región centroamericana. Según Werner Mackenbach (2011), estos referentes, dentro de la literatura de posguerra, están relacionados con la presencia de la violencia desde la Conquista, y se encuentran presentes durante el régimen colonial y durante el proceso de formación de los Estados-Nación, así como durante los conflictos armados y las guerras desde el siglo XIX hasta el siglo XX (5).

Dentro de este contexto, las subjetividades subalternas alegóricamente representadas en la literatura de Hernández aparecen dentro de una estética conformada por personajes violentados, los cuales coexisten en desventaja, son marginalizados y aparecen como fragmentos aislados y simbólicos dentro de u $\mathrm{n}$ contexto opresivo. Los personajes se hallan expuestos a la crueldad que imponen quienes gozan del poder y legitimidad y la ejercen sobre ellos.
Los grupos opresivos en el poder imponen la degradación y la exclusión identitaria que, en clave alegórica, hacen alusión a sistemas opresivos regidos, básicamente, por sistemas de poder integrados por gobiernos, militares y élites sociales, económicas y culturales.

Cabe señalar que la estética que presenta esta autora está marcada por un simbolismo hiperbólico que provoca imaginar realidades más allá de las descritas y a percibir esas realidades en formas muy diversas, tal vez nunca percibidas en el mundo real. Estas descripciones permiten una amplia gama de interpretaciones. Algunos ejemplos de las estrategias narrativas utilizadas por Hernández que esgrimen la representación del subalterno y la violencia son, en primer lugar, la recurrencia a lo fantástico, mítico y mágico para evidenciar el "horror" y el "aspaviento" dentro de un contexto surrealista. También, están incluidas estrategias literarias como la utilización de lo "abyecto" para evidenciar aquello que perturba la identidad, las subjetividades; que perturba un sistema, un orden que no respeta los límites, los lugares ni las reglas (Pérez: 2012: 51). Por último, está contenido el uso de la deconstrucción para sobresaltar y satirizar la degradación de las subjetividades violentadas.

Estos dispositivos narrativos refuerzan también algunas propuestas temáticas; por ejemplo, la de robustecer la denuncia del estado de caos y violencia predominante en la sociedad de posguerra. Además, estas estrategias literarias crean una crítica a la ideología dominante, evidencian la ruptura entre las políticas ejecutadas por los grupos hegemónicos y los que integran otros sectores sociales. Las imágenes de violencia que presenta Hernández en su estética incluyen asesinatos secretos y sistemáticos, torturas, desapariciones, violaciones, matanzas en masa, mutilaciones; en fin, encarnan violencia, destrucción y corrupción entre otras. Las víctimas mayormente representan a la gente común, al pueblo. Son personajes ciudadanos, mujeres, pobres y niños oprimidos que ambiguamente confrontan la violencia buscando bienestar, y amor. 
El estilo de Hernández, además de contener un simbolismo colectivo y un uso de una figuratividad compleja, denota un estilo disruptivo de la narrativa convencional. Para ilustrar este estilo muestra la recurrencia a la invención de personajes y especies endémicas ${ }^{1}$, a la dislocación del tiempo y a la fragmentación del hilo conductor en las tramas de los relatos. Este estilo, tiene una fuerte intencionalidad discursiva o una sugerencia sobre la realidad: los textos ilustran una intensa crueldad, el horror y la destrucción de subjetividades con el fin de interpelar a la audiencia a replantearse condiciones de existencia opuestas. Yuxtapuesta a la violencia, los textos sugieren también la existencia de una voluntad que procura una vida en paz, una orientada hacia un devenir mejor. Algunos personajes expresan la necesidad de "lo que es digno de considerar, admirable y valioso" (Taylor: 1996) dentro de un imaginario social.

Interpreto que al hacer esta yuxtaposición de estados opuestos de horror y de bienestar, la autora marca una diferencia con su escritura respecto a otros autores de la literatura de posguerra. La narrativa entreteje la intención de sembrar una concientización sobre el grado de degradación de la realidad en sus imaginarios, una degradación que cultiva un malestar positivo en el lector. Es un malestar que mueve interiormente y concientiza sobre el horror de la violencia y la conveniencia de la paz.

Para mostrar lo anterior, comienzo el presente análisis con el esbozo de la representación de las subjetividades dentro del imaginario creado en los cuentos de Hernández. Es decir, examino la descripción de las "bestias" simbólicas y los escenarios simbólicos y degradados en los relatos.

\section{Animales del bestiario, los buitres}

“dos lóbregos pájaros [que] atraparon [a la tórtola] en el aire y la devoraron con fiereza ante sus ojos impotentes" Claudia Hernández.

Empiezo haciendo referencia al compendio de bestias/personajes que aparecen en la narrativa de Hernández, principalmente a aquellos que han sido compilados en el libro bajo el título De fronteras (2007). Muchos de los personajes de estos cuentos son seres/ animales que, por su comportamiento fuerte y violento, adoptan las características de bestias. En algunos casos aparecen criaturas animalescas, monstruosidades simbólicas, especies endémicas, hombres mitad humano, mitad animal, hombres mutilados y deformes que viven su existencia en un submundo ficticio y simbólico. Generalmente, cohabitan en ambientes abyectos y escatológicos imbuidos de fluidos y olores corporales como la caca, orines, sangre y basura. De hecho, un leitmotiv que predomina en sus relatos es la asociación que Hernández hace entre lo humano y lo animal. La presencia de este leitmotiv tiene como propósito evidenciar la tendencia instintiva y salvaje de los personajes, siempre propensos a la violencia y a la irracionalidad. Esta asociación de lo instintivo, libidinoso y animal al "principio de placer" freudiano que rige el aparato psíquico y que alberga impulsos y aptitudes tanto para el amor como para la agresividad (Freud: 1930: 20), nos hace pensar que los personajes/bestias de Hernández representan ambos impulsos. Ambiguamente, en el comportamiento de las bestias predomina el uso de la violencia y la agresividad utilizada para satisfacer sus intereses. Pero, por otro lado, existe también otro grupo menor de personajes bestias que lo que buscan es la cercanía del otro y su amor.

Por la ambigüedad de su representación, el compendio de bestias puede categorizarse en dos grupos. El primer grupo de bestias al que me voy a referir lo componen los personajes abyectos asociados al ejercicio de la violencia. Asocio estos personajes a diversos sistemas de dominación y poder. El segundo grupo, los personajes más orientados a la búsqueda del bien, los relaciono con las subjetividades violentadas y subalternas. Dentro del primer grupo, la referencia asociativa más directa de un personaje a una bestia es la que describe a un buitre en el cuento "Lázaro, el buitre" (Hernández: 2007b). 
Lázaro es un personaje abyecto: un buitre al que le gusta lamer sangre y comer carne de muerto. Físicamente, es un personaje deforme y monstruoso, vulgarizado, mitad humano, mitad animal. Aunque también calza la descripción de un zopilote, a Lázaro nadie lo excluye por ser buitre, con garras, pico y alas; por el contrario, lo aceptan por tener "clase" y ser un ciudadano distinguido. Pero Hernández (2007b: 51) recuerda al lector que "bajo el traje y la sonrisa, era un buitre como los otros". Lázaro no solo volaba alto, era gracioso y amable, "caminaba por la ciudad soltando frases corteses al aire y provocando pláticas en cada esquina" (Hernández: 2007b: 51), sino que además, poseía las características de un animal depredador y devorador: un buitre. Era un personaje carnívoro que come entrañas (Chevalier: 1995: 205) y se aprovecha y se nutre de los demás. Él siempre estaba atraído por la sangre y la carne humana y deseaba comerse a la hija del narrador. Pero al lamer con avidez la sangre de la hija del narrador, éste le dispara y mata en su afán por defenderla.

Este personaje cae en la dicotomía de protector y demonio. Por un lado, al representar a un buitre bien puede asociarse a quienes controlan el poder y quieren "proteger" a los otros: se muestran amables, respetuosos y benefactores de los indefensos; y por otro, usan a otros personajes para satisfacer sus necesidades canibalísticas y sus gustos con saña y alevosía. Calculan, controlan, son aprovechados, codiciosos e impuros puesto que actúan en forma de animal carnicero sin el mínimo respeto a los valores que resguardan la vida humana. Hernández los describe "amables" y modosos, pero bajo sus máscaras encubren sus macabras intenciones ya sea de explotar, saciarse o matar con indulgencia. En este sentido, el también escritor salvadoreño Manlio Argueta (2008), en El valle de las hamacas, hace alusión a estas aves de rapiña llamándolos pájaros zopilotes:

\footnotetext{
... y así quién va a querer hacerles competencia a estos cabrones [los pájaros que usan uniformes militares cosidos con hilo de oro] esa es la historia del país mientras los diferentes cuelgan de los árboles amenazados por los zopilotes en las
}

montañas no sin haberles sacado la masa encefálica ... así pasa con aquellos que tratan de cambiar la atmósfera cargada de hedor. (Argueta 2008: 33)

Los "cabrones" zopilotes (buitre negro americano) que amenazan a los "otros" diferentes aluden a quienes se envisten de poder. De forma menos simbólica y más literal que Hernández, la cita anterior describe a los militares durante los movimientos insurgentes, puesto que visten con uniformes cosidos con oro y tienen la potestad de descerebrar a los otros y con este acto aniquilarlos.

En el relato de Hernández, sin embargo, la asociación figurativa de los buitres a los sistemas de dominación y poder se desprende de la descripción que ella hace de las intenciones del personaje y de sus maneras de actuar. En ambos casos, los buitres bien pueden ser una alegoría del poder y quienes han sido protagonistas en la historia salvadoreña: a los políticos "ciudadanos distinguidos", a los militares, y a los miembros de la clase oligárquica, quienes, durante el período de preguerra ${ }^{2}$ y durante la guerra, se abocaron a perseguir, desaparecer, masacrar, torturar y violentar a los más débiles e indefensos (a lamer la sangre), sobre todo durante el establecimiento de los regímenes autoritarios y represivos en El Salvador. Lázaro representa "un peligro", pues es quien desde arriba "vuela alto" sobre quienes reciben sus acciones abajo. Lázaro primero "marca" o señala al cuerpo vulnerable de la niña. La diferencia, la somete $\mathrm{y}$, finalmente, ejerce sobre ella su poder a fin de satisfacer sus necesidades.

En forma similar, los buitres pueden también representar a los sectores que controlan las políticas neoliberales. A quienes explotan, someten y se nutren de otros, otros que pueden ser los trabajadores, los operarios, los migrantes y los pobres. Estos últimos, para satisfacer sus necesidades básicas, aceptan su propia explotación laboral. Asimismo, el buitre bien puede ser el hombre en el sistema del poder patriarcal que quiere "devorar" a una niña para satisfacerse sexualmente. La niña representa al "cuerpo dócil": objetos de blanco y poder a quienes se manipula, se da forma, se educa: 
objetos que obedecen y, entonces, responden (Foucault: 1984: 123).

$\mathrm{Y}$ finalmente, el buitre puede ser quien goza de legitimidad social y cultural y tiene el derecho de violentar al "otro" diferente. Un ejemplo simbólico de este tipo de buitres lo constituyen los ladinos quienes al ostentar un modelo de subjetividad eurocentrista justifican la invisibilizacion del indio ${ }^{3}$. De igual forma, el buitre puede representar a los miembros de las élites cultas ${ }^{4}$ que por haber adoptado los hábitos políticos, económicos, sociales y culturales modernos respaldándose en el conocimiento y su academicismo, creen que pueden violentar a los más débiles.

Pero la asociación simbólica más directa es la del buitre con el estereotipo de un político actual. Usa traje, es cortés, platica amablemente con todos $\mathrm{y}$, principalmente, no usa la violencia directamente: lame la sangre de la niña "con avidez" sin que la esposa del narrador viera las "malas intenciones" del hombre-bestia (Hernández: 2007b: 52). Al asociar al político con un personaje abyecto, la narración le adscribe características asquerosas que le permiten al lector percibir repulsión hacia él.

Por su parte, el narrador de este relato también se enviste a sí mismo de poder, como una forma de resistir el abuso y de luchar contra la explotación sugerentemente sexual de la niña. El poder aquí funciona en ambos sentidos para Lázaro y para el narrador en medio de una relación de poder que utiliza la estrategia confrontativa. Citando a Michel Foucault, el texto ejemplifica la estrategia donde se priva a un oponente de sus medios y se reduce hasta obligarlo a abandonar la lucha (Foucault citado en Dreyfus y Rabinow: 2001: 257). Aparentemente, Lázaro muere en esta interacción.

Además, por su nombre, Lázaro, hace referencia al ser "humano" que nunca muere. Dentro de la fe cristiana, según el evangelio de Juan (11: 1-44 Versión Reina Valera), un hombre llamado Lázaro es resucitado por Jesús, el hijo de Dios, después de haber estado muerto por cuatro días. Lázaro se levanta de entre los muertos y vuelve a vivir. Asimismo, dentro de la simbología maya, el buitre por alimentarse de carroñas e inmundicias puede considerarse como agente regenerador de las fuerzas vitales, como purificador que asegura el ciclo de la renovación transmutando la muerte en nueva vida (Chevalier: 1995: 205). Con su nombre, el relato le adscribe figurativamente a Lázaro el poder de "resucitar" una vez que el narrador lo acribilla. Con esto se sugiere que el hombre/ bestia continuará renovándose dentro de un ciclo vicioso que resulta imparable en la historia. Con este personaje se sugiere la personificación de la representación del poder ya sea en manos del político corrupto, del militar opresor, del explotador "devorador", quienes siempre tendrán su lugar en la sociedad a través de la historia y continuarán ejerciendo el poder sobre los débiles subalternos.

Si continuamos con el bestiario, veremos que Hernández realiza otras referencias similares a la anterior en donde la narración juega con la figura del pájaro. El narrador no los llama directamente buitres, pero les atribuye las características de estas aves de rapiña. En el relato "Los pájaros" (Hernández: 2001c: 8) en el libro La canción del mar (2007), estas aves son "dos lóbregos pájaros [que] atraparon [a la tórtola] en el aire y la devoraron con fiereza ante sus ojos impotentes". Los siniestros pájaros metafóricamente representan a devoradores de niños: los "ojos impotentes" pertenecen a "un niño, a una tórtola" a quién después le sucede lo mismo que le sucedió a la joven ave. Este niño, al igual que la tórtola, se convierte en presa de otros cuando apenas aprendía a "volar".

Similar situación ocurre en "El cerco de las acacias" (Hernández: 2007c: 8). Las bestias son: “... aladas criaturas de cuatro patas y arrugados rostros que se posaban sobre las ramas ... y le enseñaban [a un niño] a llamar a otros seres que esparcían por el lugar un penetrante olor similar al de los nidos de las serpientes" (Hernández: 2001c: 8). Las connotaciones atribuidas a las aves en estos últimos relatos son malévolas ya que estos animales, con sus malas intenciones, corroen. Ellos se nutren de la carne de los indefensos niños y se valen de su fuerza. Con sus potentes picos y garras, destruyen a 
las mentes de estos niños y/o toman la carne de sus cuerpos para alimentarse. Simbólicamente, a sus presas no solo les usurpan su inocencia, sueños y vidas sino también una existencia potencialmente saludable. Como consecuencia del ataque, los niños abandonan sus vínculos familiares y uno acoge "el corazón del marino y las sombras que lo habitaban" (Hernández: 2001c: 8). Además, estos "pájaros" son rapaces, es decir, toman a sus presas por la fuerzaactúan con "fiereza". Sus garras son certeras y, para destruir a sus presas, cuentan con un fuerte pico curvado que desgarra la carne.

Pero ¿a quién podría estar aludiendo figurativamente Hernández con estos pájaros? Según las interpretaciones de Chevallier (1995), los pájaros o aves connotativamente representan a diferentes criaturas: por su vuelo, son símbolos de las relaciones entre cielo y tierra, pero, por su nombre en griego, son también sinónimos de presagio y de mensaje del cielo. Son figuras inmortales, según el taoísmo, que liberan la pesadez terrenal y que gozan de una espontaneidad primordial, violenta e incontrolada. Además, se asocian a ángeles, a estados espirituales y superiores del ser. Son además mensajeros y auxiliares de los dioses cuya función es representar la amistad de ellos hacia los hombres $(154,155)$. En el caso de los relatos, si las aves se comparan con los significados simbólicos descritos, la representación de los pájaros es connotativamente irónica.

Si los pájaros deben establecer relaciones entre dioses y humanos, ya sea como libertadores, mensajeros, ángeles y auxiliares de los dioses, su presencia en los relatos está deconstruida. Ellos en vez de auxiliar y proteger desde el cielo y conectar a los personajes con fuerzas espirituales superiores, más bien caen sobre sus víctimas para destruirlas física o espiritualmente. Ellos solo buscan satisfacción personal a costas de otros. Como los buitres, representan a quienes controlan el poder y lo ejercen desde arriba (cielo) sobre otros más débiles y volubles (en la tierra). También coartan las acciones de otros y su derecho y capacidad para vivir y crecer. Como el buitre, según el Corán, el ave o el pájaro se puede tomar como símbolo de la inmortalidad del alma (Chevallier: 1995: 156). Es decir, estas criaturas que gozan de poder para inmortalizarse, siempre estarán presentes entre los humanos. Entonces, a partir de los relatos, se puede interpretar que seguirán ejerciendo el poder de la misma forma violenta sobre otros indefensos. Los buitres y pájaros representan a los que tienen poder sobre los débiles, sus cuerpos, sus mentes y su subjetividad. Este tipo de relación de poder puede dilucidarse también según Foucault (1984) ${ }^{5}$ : quienes dominan ven en los cuerpos de sus dominados un espacio geopolítico sobre el cual se imprimen marcas; el cuerpo se doma, se somete o se fuerza a conductas mediante la violencia (25).

Haciendo una correlación con la realidad, los pájaros son personajes abyectos que pueden simbólicamente representar a varios agentes sociales que ejercen el poder sobre otros en condiciones de desventaja: ¿Adultos abusadores de niños? ¿Quiénes imponen conductas y modelos de subjetividad sobre otros despojándolos de la oportunidad de desarrollar su propia identidad? ¿Quiénes en la historia sometieron a otros grupos o culturas "menos civilizadas"? ¿Quiénes se aprovechan de legitimidad cultural y política y se imponen marginando la diferencia y otredad? ${ }^{6}$

Evidentemente, las aves de rapiña gozan de un alto nivel de superioridad sobre las tórtolas. Poseen condiciones aventajadas desde su posicionamiento social, condiciones con las que superan a otros más débiles e indefensos. Estas aves de rapiña y depredadores carnívoros evidencian la violencia ejercida sobre otros, ejemplifican la desigualdad y la exclusión.

Otros animales que conforman el bestiario de Hernández y que sugieren representar al sistema de poder patriarcal son los perros y/o los perros lobos. Estos animales persiguen a sus víctimas, las despojan, las invalidan y las atacan. En general, las víctimas son mujeres. El lobo y los perros lobos muestran en los relatos un alto grado de violencia, ejemplificando la definición simbólica que dice que el lobo es sinónimo de salvajismo y evoca una fuerza mal contenida (Chevalier: 1995: 653). Una representación de los 'atributos' consignados a este animal la encontramos en los relatos "Nadia” (Hernández: 
2001: 16-25) y en "La han despedido de nuevo" (Hernández: 2005: 29). En el primer relato, el perro-lobo que persigue al personaje de Nadia, habla, saluda y sonríe reverentemente, pero también amputa su mano derecha, la carga en su hocico. Este acto imposibilita a Nadia para trabajar, marginando su condición existencial y social e invisibilizándola dentro del sistema productivo. Ella sufre la violencia ejercida sobre su cuerpo y la degradación: pierde su trabajo, pierde una oportunidad para el amor y se ve obligada a trabajar en un puesto muy por debajo de sus aspiraciones. El poder aquí representado es el del hombre dominador sobre la mujer a quien éste abusa, subyuga, somete y violenta como sucede dentro del patriarcado, un sistema de dominación histórico y universal. Además, él corta su mano, un acto simbólico que imposibilita a Nadia a recibir y dar "cosas" con ella.

Similar situación se da en el segundo relato "La han despedido de nuevo". Aquí el lobo es un seductor que usa a su víctima Nuna, una migrante salvadoreña voluble e indefensa que vive en Nueva York. El animal la persigue para su satisfacción sexual, la usa para reproducirse $\mathrm{y}$, ante una situación de embarazo, la abandona. Luego, otro hombre, el señor Orestes, de nuevo la toma, la abusa, la confina a una pocilga y pretende quitarle al niño. El lobo, símbolo de salvajismo, engaño, ferocidad y voracidad, puede asociarse al patriarcado que presenta al hombre como protector pero que es en realidad un abusador mentiroso que usa y abusa de las mujeres. Esta representación del patriarcado toma ventaja de los privilegios que le da el sistema y se aprovecha de Nuna y de la condición de vulnerabilidad en que ella se encuentra por ser migrante.

Este lobo ni siquiera puede pronunciar el nombre de Nuna en español. Además el lobo es descrito como uno de piedra y del tamaño de un automóvil que se pasea por los tejados de los edificios. Él llama a Nuna con un nombre que no es el suyo y la invita "en español" a jugar. Después de pasar tres días con ella, el animal la abandona después de haberla usado sexualmente (Hernández: 2005: 30-60). La sugerencia aquí es que el hombrelobo trabaja para alguna agencia de poder: migración o alguna oficina gubernamental. Esto se desprende de la descripción: es grande y fuerte como una piedra y camina en las "alturas" sobre los techos y no puede hablar español ni pronunciar el nombre de Nuna.

El sistema representado en el texto, sea el patriarcal y/o el policial-migratorio, ilustra la propuesta foucaultiana de las relaciones de poder en donde quienes gozan de poder "fuerzan" a los subalternos a actuar de acuerdo a sus intereses. A Nuna la subyugan y la usan. A ellos se les utiliza pero no se les quiere integrar socialmente al sistema. El sistema policial migratorio también actúa como un panóptico desde donde los migrantes son vigilados, perseguidos y disciplinados para "normalizarlos". No obstante, esta normalización tiene que ver con la asimilación y la explotación productiva y no con una participación social, cultural o política activa. El imaginario representado en estos relatos es uno metafóricamente caníbal: uno que aísla, explota y violenta a ambos personajes, Nadia y Nuna, victimizándolas y marginando sus vidas. ¿Actúan los representantes de los sistemas de dominación como los lobos? Los hombres en las calles, los dueños de restaurantes o "diners", los administradores, los jefes, utilizan su posición aventajada para demandar favores de personajes como Nadia y Nuna.

Es también significativo el simbolismo de sus nombres: Nadia puede asociarse con "nadie" y Nuna con "no una", o "no es una". Estas asociaciones sugieren la invisibilización de sus identidades. Esta falta de una representación identitaria dentro del sistema que las margina, excluye y degrada. Por otra parte, el sistema dominador capitalista-explotador al que pertenecen estos personajes alude al contexto donde el relato se desarrolla: en la ciudad de

Nueva York. Este sistema económico capitalista neoliberal pretende explotar a los personajes disminuyendo su avance económico y social. Seguidamente, continúo describiendo la asociación del bestiario con los subalternos. 


\section{Animales del bestiario, las víctimas}

Por otra parte, Hernández también menciona a otros tipos de animales para describir a los personajes subalternos. Considero que a diferencia de las bestias descritas anteriormente, la autora simboliza a los subalternos con otro tipo de animales igualmente abyectos pero con el fin de "cifrar, pensar y exorcizar el legado de violencia" (Kristeva citada en Pérez: 2012: 51). El propósito es enfatizar la degradación que sufren en su condición de invisibilizados y dominados en dos sentidos: son reducidos y rebajados a vivir en condiciones típicas de los animales, permitiendo de esta manera la negación de su humanidad y la diferenciación marginalizante que los victimiza. Además, los personajes de este grupo viven en submundos escatológicos que representan las condiciones de existencia degradada.

Personajes-animales como los descritos en el cuento "Fauna de alcantarilla" (Hernández: 2007b) ilustran simbólicamente a los subalternos, principalmente por su condición de pobreza. De hecho, el cuento se refiere a ellos solo como "fauna" evitando descifrar el tipo de animal que representan. Con esto, uno puede interpretar que puede ser cualquier miembro del magno reino animal, son personajes miembros de diversos tipos de familias faunísticas. En el relato, las condiciones infrahumanas y abyectas en que viven los miembros de una familia, los reducen a un estado más bajo que el de un animal doméstico. Los personajes en este relato viven y se esconden en una cloaca debajo de la calle, siendo el padre únicamente quien sale desnudo a cazar gatos y perros para comer. Este personaje tiene todas las características de un reptil: tiene la piel escamada, caza a sus presas clavándoles las uñas y las devora. Además, muerde para protegerse de los extraños. A él y a su familia no les recibieron en el zoológico porque allí solo cuidan y atienden animales. Al final del relato, los vecinos sellan la alcantarilla para que estas criaturas dejen de comerse a sus mascotas. Después de un tiempo de escuchar los lamentos, la familia muere asfixiada esparciendo el olor de sus cadáveres por el vecindario.
Por la descripción magnificada de su aspecto, estos personajes abyectos inspiran asco y repugnancia y, por su conducta, sugieren ser monstruosidades que devoran "mascotas" para alimentarse. La repulsión que evoca este tipo de familia por el hecho de ser diferente puede asociarse a la percepción que existía hacia las subjetividades otras excluidas subalternas. Un ejemplo en la historia lo provee el testimonio de Rigoberta Menchú refiriéndose a la percepción que existía hacia los indios: según ella, estos eran considerados no gente, una clase animal peor que un gato cagado (Menchú citada en Gallardo: 1993: 117).

En Hernández, los personajes de la familia/reptil se asocian a lo "anormal", a lo abyecto y a lo monstruoso porque tal y como argumenta Foucault (2007) en Los anormales, por su apariencia y por sus prácticas sociales se apartan de la normalidad, una normalidad protegida, según él, por un continuum, a través de un discurso envestido de verdad legitimado por la institucionalidad dentro del cuerpo social (la médica, legal e histórica) y constituyente de lo que es anómalo, represivo y punitivo (19). Ellos son vistos físicamente como monstruos por los "vecinos", los que gozan de "legitimidad cultural" (Cortez: 2002) y determinan la normalidad y la verdad. Ellos confinan a esta a familia a vivir recluidos separados de los demás (asilo) por su "anormalidad". Son personajes reptiles que el narrador describe "raptando" con "la piel escamada" (Hernández: 2007b: 63), viviendo entre la inmundicia y comiendo animales para no morir de hambre. Por sus cuerpos diferentes, sucios y abandonados y por sus prácticas inusuales, los vecinos los esconden $\mathrm{y}$ al final los eliminan. Estas situaciones ejemplifican al poder "que funciona en red [vecinos] y cuya visibilidad no solo radica en la docilidad y la sumisión sobre los que se ejerce el silencio" (Foucault: 1973-1974).

Los "vecinos" determinan las estrategias de disciplina que deben ser aplicadas a esta familia por su "anormalidad". Los vecinos responden al peligro que significa la cercanía del anormal y crean las formas de protegerse mediante el ejercicio del control: los vigilan, 
expían e invisibilizan. Así, los mismos primero solicitan la detención del hombre/reptil, luego lo atrapan pero, como no podían detenerlo en la policía, intentan enviarlo al zoológico, en donde tampoco lo aceptan, y al final deciden matarlo a él y a su familia. El destino de esta "anormal" familia es la destrucción y la muerte. A ellos o se les "normaliza", o se les desaparece de la sociedad.

Estos actos en contra de la familia/ reptil ilustran, en forma simbólica, a otros cometidos en contra de los subalternos dentro de algunos sistemas de poder en la historia por ser "diferentes" o por salirse del continuum de homogeneidad social al que hace referencia Foucault (1984). Ellos pueden figurativamente representar a diversos grupos subalternos en la historia: los nativos, indios y negros a quienes se percibían como monstruos, salvajes, bárbaros conviviendo en un mundo incivilizado y primitivo, similar a una "cloaca". También, pueden representar a otros "anormales" por salirse de las prácticas hegemónicas como los pobres, los campesinos, los analfabetas y los exrevolucionarios y exguerrilleros. El conflicto en el relato entre los representantes del poder, los vecinos, y los subalternos evidencia una gran brecha social. ${ }^{7}$

Otro ejemplo que nos ilustra la historia de los subalternos que son comparados con animales lo constituyen los trabajadores rurales en El Salvador. Ellos eran tratados peor que un animal de granja porque según la oligarquía ${ }^{8}$ (terratenientes, hacendados y productores), estos animales tenían más valor. La degradación aquí funciona para apelar a la conmiseración humana: ¿Por qué se les compara con reptiles? ¿Por qué deben comer animales? ¿Por qué se les confina a vivir en un submundo? ¿Por qué los matan asfixiándolos? ¿Exterminan a los diferentes solo por negarse a aceptar la otredad? Otra observación también válida es que al considerárseles animales, se les adscribe una identidad fija, degradada, anomalística y $\sin$ posibilidad de movilidad social. Estas condiciones favorecen la explotación.

El buey muestra también connotaciones asociadas a los subalternos y a los "anormales".
En “Carretera sin buey” (Hernández: 2007 a: 23), el personaje llamado "hombre" quiere convertirse en buey después de haber arrollado uno. Es más, se desnuda, pone cuernos, y se castra con una botella quebrada para convertirse en este animal. Aunque en primera instancia puede interpretarse que el deseo del hombre es degradarse de su condición de humano para convertirse en buey; también existen definiciones simbólicas positivas consignadas a este animal. Chevallier (1995) consigna diferentes significados metafóricos y ambivalentes al buey: por un lado, es un símbolo de bondad, calma, de fuerza apacible pero, por otro, es también uno de potencia y fuerza para el trabajo y para el sacrificio. También es un animal que puede abrir los surcos "intelectuales" para recibir las lluvias fecundas del cielo (202203). Además, según los griegos, el buey es un animal sagrado que a menudo se da en sacrificio (Chevallier: 1995: 203).

De acuerdo con estas descripciones simbólicas, el buey puede asociarse al perfil modelo de un trabajador: son leales, mansos, fuertes, sacrificados y dominados por otros y, de esta forma, puede vincularse a los subalternos. Como parte de la fuerza productiva, tanto el buey como los subalternos contienen todas las características que los calificarían como trabajadores óptimos. Por su "docilidad" y disposición al trabajo, el subalterno, representado por el buey, constituye una "fuerza útil ... es a la vez un cuerpo productivo y un cuerpo sometido" (Foucault: 1984: 25). El subalterno representado por el buey ilustra, lo que podría llamarse "una tecnología del cuerpo" - un reconocimiento de un cuerpo (dócil) y un dominio de sus fuerzas que componen una microfísica del poder que algunos aparatos e instituciones sobreponen en algunos (Foucault: 1984: 26). El relato podría estar aludiendo y criticando con este personaje a quienes pasivamente son explotados en el trabajo y quieren seguir viviendo al margen del sistema. También, la situación en la trama ilustra la indiferencia ante la marginalización, una situación similar a la presente en "Lluvia de trópico" (Hernández: 2007 b: 67) en donde los personajes insisten vivir en medio de la caca. 
En este sentido, Beatriz Cortez (2002) comenta que la subjetividad degradada de este hombre-animal buey está determinada por otros, ya que el cuento es narrado desde la perspectiva de quienes ocupan un centro de legibilidad y son ellos quienes definen su identidad (5). Asimismo, ella asocia al buey con un símbolo de fijación de la identidad: ella sugiere que la posibilidad de transformación de identidad se minimiza con la pérdida del buey. Y al igual que al hombre/reptil también se limitan las posibilidades de movimiento y avance social. Sin embargo, en el caso de este relato, el deseo del hombre de convertirse en buey refuerza la idea de la degradación humana. El personaje no quiere fijar su identidad sino que quiere rebajarla al nivel de un animal manso propenso a ser explotado en el trabajo.

Pero enfocando el análisis desde otra perspectiva, aparte de las condiciones degradantes que victimizan al hombre/buey, este personaje también proyecta una luz simbólica; una luminosidad que en la narrativa de Hernández representa el amor y el bien. Para ilustrar, el único detalle que aleja al individuo de convertirse en este animal es su mirada a la cual el hombre debía "restarle luminosidad" (Hernández: 2007b: 25). Este detalle marca la diferencia: metafóricamente "la luminosidad" viene a representar lo "sagrado" del animal: su bondad y apacibilidad. Pero, más que eso, representa su disposición de darse en sacrificio para potenciar los "surcos" que reciben "las lluvias fecundas del cielo". Es decir, es un ser que abre un camino fecundo que permite la movilización "intelectual" y social. Representa además un motor interno que es central en su carácter: una pasión que mueve la capacidad espiritual transformadora del ser humano $\mathrm{y}$ lo diferencia de un animal. Es una fuerza instintiva que lo mueve a no degradarse en su camino de muerte.

La luminosidad representa también el reservorio de amor que es parte del "yo" freudiano. Según Freud (1930) este reservorio encierra una aptitud orientadora para procurar la felicidad en la vida y desde él deriva toda satisfacción y bienestar humano (26). Esta interpretación se desprende del hecho de que, a pesar de todos los intentos de este sujeto de convertirse en animal/buey, esta energía (luz) interior se lo impide. La sugerencia es que a pesar de la determinación consignada al hombre/buey por quienes lo explotan, ellos no pueden coartar del todo el potencial humano de desarrollar su agencia, de tener aspiraciones de avance y progreso, de amar y buscar el bien.

Una situación similar se presenta con el personaje reptil/ hombre en "Fauna de alcantarilla" (Hernández: 2007b). Él puede verse como reptil, como un animal rastrero con la piel escamosa, como un animalejo que se come las mascotas de sus vecinos, pero es también un ser afectuoso. El amor se manifiesta por la forma cómo él protege a su familia; y a la vez, por la forma cómo su familia responde cuando se escapa de los vecinos y éstos escuchan "la celebración de la familia por el regreso". De esta forma se evidencia un sentido de afiliación afectiva. Este personaje lucha contra el sistema de poder representado por los vecinos aunque, al final, éstos terminen matándolo.

El amor también está presente en el relato "Los pájaros" (Hernández: 2007c: 7). La familia de la "tórtola" ultrajada alivia el sufrimiento causado por las aves de rapiña y la protege: "los miembros de la familia hablaron con él hasta que dejó de sufrir por eso ... luego despidieron al jardinero y espantaron a la bandada de pájaros" (Hernández: 2007 d: 7). También, la necesidad y el amor hacia el otro se ilustran con la imagen de la madre que protege a su hijo en "El cerco de las acacias" (Hernández: 2007c: 8). Esta madre "se inquietó y ordenó a los empleados que averiguaran lo que hacía su hijo solo fuera de la casa" (Hernández: 2007c: 8). En realidad, ella intentaba alejarlo de "las criaturas aladas de cuatro patas y arrugados rostros" que desde los árboles lo llamaban para que percibiera el olor que expedían "similar a los nidos de las serpientes". La madre intenta alejarlo del peligro de las aves de rapiña que sugerentemente parecen representar las drogas.

Otra representación de una bestia asociada a los violentados subalternos aparece en "Molestias de tener un rinoceronte" (Hernández: 
2007b: 11). Este animal tiene significaciones diversas en el relato. Al personaje principal, un joven sin brazo, pareciera que lo persigue un rinoceronte aunque ambiguamente el narrador sugiere que éste no existe:

Uno ... tiene que andar por las calles soportando que la gente lo mire, le sonría y hasta platicar de lo lindo que está su rinoceronte, señor, no lo compró acá, ¿verdad? ¿De qué rinoceronte me habla, señora? Del suyo, por supuesto. Disculpe, se equivoca ... les aseguro mientras me aseguro de que estén viéndolo a él y no a mi brazo que no está. (Hernández 2007: 11)

La sugerencia del texto es que este gran animal, esta bestia, está sustituyendo simbólicamente al brazo del personaje del texto. Si consideramos lo anterior, el rinoceronte viene a formar parte de un violento desmembramiento y desgarramiento del cuerpo y, por eso, es también el recuerdo cotidiano de su mutilación. El rinoceronte viene a representar un evento de violencia que al estar asociado simbólicamente a un animal longevo, fuerte y potente, uno podría interpretar que se trata de una alusión a un padecimiento humano que se caracteriza por viejo, enorme y duradero como la violencia.

Por las características del animal, el padecimiento puede estar entrecruzado con ciertos eventos en la historia. Por tratarse de un desmembramiento, el animal sugerentemente refiere a las mutilaciones, torturas y ejecuciones por parte de los Escuadrones de la Muerte en sus operaciones limpieza que dejaron a muchos sujetos mutilados. Estos militares se abocaron a inmovilizar a las fuerzas políticas populares así como al pueblo en general antes de la guerra civil. Los actos ejecutados por estos escuadrones recuentan las expresiones más extremas de violencia sobre la población civil. La bestia, el rinoceronte, por su tamaño y longevidad, alude simbólicamente a este tipo de violencia. Además sugiere la constante presencia y prolongación de la violencia en la sociedad después de la guerra.

Sin embargo, el rinoceronte, aunque significa un problema para el hombre, llega a ser el amigo, el compañero de vida que mira a su dueño con amor. Realidad o fantasía, el rinoceronte en sí mismo ofrece representaciones simbólicas de los estados internos y externos de un personaje solitario y mutilado que deambula en una ciudad extraña. El rinoceronte simboliza una mitad referida a la agresividad y otra mitad referida al amor que constituye al ser humano según Freud. Por un lado, él es una carga, una marca corporal, en donde el cuerpo es una superficie de inscripción de la violencia, un espacio de disputa, un campo de batalla que lleva inscrita las huellas del combate (García: 2000: 12). El rinoceronte es la marca que mantiene la memoria viva (1932) de un conflicto sin solución, visible, puesto que el rinoceronte vive muchos años y tiene mucha fortaleza. Y por otro, el rinoceronte también simboliza al amor. El protagonista ha aprendido a apreciarlo, aunque sea un referente de violencia. El animal ha venido a constituir parte de su historia, una

historia que le ha dado la oportunidad de ver la vida distinta: él mira al hombre con amor y éste responde igual.

En esta situación es evidente la presencia de la fuerza regeneradora de vida y amor: el hombre acaricia al rinoceronte con los dedos que no tiene y le permite dormir con él (Hernández: 2007b: 13) ¿Sugiere el texto que el hombre necesita. Y depende, del rinoceronte y todo lo que éste representa? Todo parece indicar que sí. Él depende de su pasado cruel. Aquí entra de nuevo la ironía y la deconstrucción al invertir el deseo de vivir en un estado de privilegio, de paz y sin problemas tan grandes y duraderos (como la violencia) por un deseo de vivir con el rinoceronte y todo lo que éste representa.

Continúo el análisis interpretativo de la condición subalterna relacionada ahora con contextos animalistas.

\section{El contexto de los animales, insectos $y$ bestias}

El escritor y cronista salvadoreño de preguerra Roque Dalton describió a El Salvador desde la perspectiva de los conquistadores como un submundo en su collage de crónicas y poemas en Las historias prohibidas de pulgarcito (1988). En "Paisaje y hombres (1576)", Dalton describe el submundo como un lugar plagado de pestilencia, 
mosquitos de "cuatro géneros", moscas, avispas, alacranes, gusanos peludos, "cientopies" malos y venenosos, culebras y víboras, escarabajos y especies que "crían cornecuelo en la cabeza, que los malos usan para sus sucias lujurias, de efecto extraño" (20). El pasaje anterior describe la definición del espacio geográfico desde la perspectiva de un narrador español en la Conquista. Dalton la publica para describir las apreciaciones negativas del territorio geopolítico en aquella época, aunque aludiendo también a épocas posteriores.

Estas apreciaciones están ligadas a la pestilencia, las plagas, la maldad y lo vil. Evidencian una descripción abyecta del entorno. En esta descripción hay una clara sugerencia simbólica de que el entorno es salvaje y dañino. Esta percepción irónica, hecha por Dalton desde la perspectiva de las metrópolis y los conquistadores, bosqueja simbólicamente el tosco espacio geopolítico en la región. Desde el inicio de la historia de El Salvador, las descripciones de las condiciones nefastas ${ }^{9}$ adscritas al contexto, han estado asociadas al habitad de sus ocupantes. Hernández representa simbólicamente este habitad para denunciar las condiciones abyectas en que viven los subalternos. Las narraciones describen personajes encarnados en insectos o animales viviendo en sus submundos con el fin de enfatizar la degradación y la marginalización que caracteriza la subalternidad.

El cuento "Trampa para cucarachas" (Hernández: 2007b: 72) se desarrolla en imaginario abyecto. Este imaginario remite a una alegoría de la violencia y la falta de solidaridad que se relata desde la conducta de un personaje inmigrante sin nombre que vive en la ciudad; una representación de la ciudad que tiene anclaje en la realidad salvadoreña (Cuvardic: 2013). El personaje vive en una pocilga horrenda plagada de cucarachas. Las cucarachas condicionan el ambiente y el estilo de vida que lleva el personaje: las cucarachas caen del techo, el techo gotea y suda cucarachas que llueven sobre él (Hernández: 2007b: 76). Estos insectos figurativamente definen la identidad del personaje al posicionarse jerárquicamente como seres superiores a él: él es menos que una cucaracha, menos que un insecto que habita en la suciedad y en la basura, que contamina el ambiente y constituye un riesgo sanitario para los demás ya que trasmite enfermedades y pestilencia. Pero este personaje se redefine y redime al tratar de erradicarlas y comérselas:

Todo me había fallado ... las dieciséis trampas ... No acudieron a comer las migas de pan ... Ignoraron las bolitas de veneno ... No le prestaron atención al plato de comida ... no pusieron una pata encima de mi ropa cuando le regué veneno para que cuando se asentaran se contaminaran ... Nada funcionó [... hasta que] yo haciéndome pasar por muerto, era el mejor cebo. Dejaba de respirar y ellas me recorrían confiadas hasta entrar en mi boca abierta, con la que las atrapaba (Hernández: 2007b: 82)

La sugerencia es que el personaje casi se convierte en cucaracha, proporcionándonos otro claro ejemplo de lo que es un "anormal", abyecto y repulsivo. Su "hazaña" irónicamente se traduce en su horizonte, le da valor existencial y él logra un triunfo personal: el personaje calma su hambre consumiendo cucarachas y se apunta un logro en su miserable vida subalterna. El supera su invisibilización ante sí mismo aunque continúa invisible en el sistema. A él nadie lo nota, con nadie interactúa, a nadie le interesa en el "hoyo negro en que vive, en donde todo asfixia” (Hernández: 2007 b: 76).

La peste de cucarachas domina el contexto. Podemos inferir aquí que las condiciones de vida de este subalterno están avasalladas simbólicamente por lo abyecto, por agentes pestilentes que contaminan, ensucian y ponen en riesgo a otros afectando la construcción de sus subjetividades. ¿Aluden las cucarachas al entorno (social, político, económico) degradado que habita el sujeto? La respuesta es afirmativa porque el hombre termina comiendo lo que encuentra en él: cucarachas. La situación de este cuento ilustra las afirmaciones de Foucault (1973-1974) cuando explica las repercusiones que tienen las decisiones de quienes ejercen un poder y cómo estas actúan sobre los cuerpos:

sucios y abandonados ... [en donde] el poder político y los poderes en general logran tocar los cuerpos, aferrarse a ellos, tomar en 
cuenta los gestos, los comportamientos, los hábitos, las palabras; la manera ... como todos esos poderes, al concentrarse en el descenso hacia los propios cuerpos y tocarlos, trabajan, modifican y dirigen ... las "fibras blandas del cerebro"

El entorno y la situación han degradado tanto al cuerpo y la mente de este personaje que éste ve la redención en lo que hace y lo considera una hazaña. En el relato, el poder se asocia al ambiente pestilente creado, a las cucarachas que actúan sobre el personaje narrador y al hoyo negro en que vive. Quienes tienen el poder han creado ese entorno: los gobiernos, el estatal, lo militar, lo neoliberal. También han creado a quienes controlan el poder económico cuyas políticas solo benefician a ellos mismos. Los otros subalternos, sobre quienes recae el poder, trabajadores asalariados y pobres, por ejemplo, sufren el "descenso" y la degradación de sus cuerpos y mentes.

Además, las cucarachas también pueden alegóricamente representar las condiciones sociales en que habitan los subalternos en la actualidad. Estas condiciones están contaminadas y corruptas: representan el abuso, la explotación, el caos, el narcotráfico, la delincuencia, la corrupción, entre muchos otros factores relacionados con la violencia. La condición del personaje denuncia una violación tácita a los derechos humanos ya que vive en condiciones infrahumanas: pobreza extrema, sin derecho al trabajo y a la educación; sufre hambre, se expone a enfermedades. En suma, se encuentra sin ayuda de ningún tipo.

Al vincular la literatura con la realidad, la situación del personaje puede explicarse, según Luis G. Solís e Isayana Baldizón (1999), a partir de las situaciones características de los años noventa. Paradójicamente para Centroamérica, este periodo constituyó un momento de transición democrática y de normalización de las relaciones económicas, comerciales y políticas, tanto a nivel interno como internacional después de una década de violencia extrema. Sin embargo, como lo afirman Solís y Baldizón, la situación social de El Salvador lejos de mejorar empeoró (1999: 4). La pobreza y la exclusión social han sido dramáticas: "más del 70\% de los habitantes del Istmo viven por debajo de la línea de la pobreza; el analfabetismo regional promedio todavía supera el $50 \%$, y los niveles de mortalidad infantil y maternal no [habían] mejorado" (11). Estas estadísticas demuestran que las políticas económicas neoliberales establecidas en la posguerra, fueron ineficientes y tendieron a intensificar la marginalización social.

La narrativa de Hernández ilustra las afirmaciones anteriores. El personaje sufre la degradación física, corporal y mental en su miseria, ambigua e irónicamente, buscando mejores alternativas de vida. El protagonista muestra una identidad degradada que adopta una visión distorsionada de su existencia y realidad: él experimenta el logro consumiendo cucarachas. Pero él mismo se encamina hacia su propia destrucción. La representación de la realidad y del entorno que vive este personaje está deconstruida ya que se invierte nuevamente el significado de bienestar y confort: el estado de vivir en la pocilga y comer cucarachas es presentado como un estado ideal. El personaje avanza hacia atrás. Con la deconstrucción, Hernández insta a relacionar sensaciones como el asco y la repugnancia con una vida de confort, evocando en su audiencia la experimentación de lo que se siente comer cucarachas y al mismo tiempo vivir "feliz".

Al final del texto, este personaje antiutópico, un hombre nómada y sin raíces, manifiesta que ahora vive feliz y que no quiere regresar a su lugar de origen. Quien ha contribuido a establecer las condiciones del entorno en que se desarrolla este personaje, se encuentra omiso, ya que no se explícita en la narración, sin embargo, es evidente que el individuo ha sido condicionado a vivir así y él, por iniciativa propia, busca formas de redimirse.

En este caso, a pesar de esta distorsionada representación de redención, también es rescatable, la necesidad que muestra el personaje de conquistar un logro. Esta necesidad es un "motor" que insta al protagonista a realizar su "hazaña" y redimirse. Es evidente que él muestra una capacidad de lucha que es valiosa $\mathrm{y}$ que se encuentra motivada por su necesidad 
de "avance" aunque sea a la inversa. El texto lo evidencia anotando que el personaje experimenta "una alegría para saborear", algo que le permite amar a don Gabriel, su arrendatario, aunque irónicamente termine ingiriendo la plaga de cucarachas. Así se evidencia la necesidad del protagonista de amar y de buscar el calor del otro.

\section{Otros hábitats de las bestias, los escenarios escatológicos}

Otros imaginarios simbólicos y ficticios que desarrolla la narrativa de Hernández están constituidos por submundos excrementicios en donde suelen habitar los personajes. Estos imaginarios también remiten a la degradación y a lo abyecto. Escenarios como el descrito en el texto Lluvia de Trópico (Hernández: 2007b: 51), según Dorde Cuvardic (2013), también trata en clave alegórica lo que se supone vivir en la degradación y acostumbrarse a ella, una realidad que también tiene anclaje en la realidad salvadoreña. En este cuento, sobresale la representación simbólica de imágenes sensoriales ya sea visuales y/o olfativas

para describir el entorno social, político y cultural salvadoreño. Argueta (2008), en forma más literal, también alude a este entorno con imágenes similares:

$\mathrm{Y}$ es que en este país todo va envuelto en, politiquería y en política el vaho del trópico no sólo está envuelto en bolas de aire seco y caliente sino en nubes de hedor una tormenta cotidiana y uno dando saltos para no caer y llenarse todo y después morir como micos oliéndose el dedo sin comer ni beber (Argueta 2008a: 32).

Ambos autores utilizan la imagen de la lluvia tropical, una tormenta que genera hediondez. Argueta $\left(2008^{a}\right)$ relaciona esta tormenta directamente con la política y las condiciones de vida subalterna en la que abundan el hambre y la sed. En la cita anterior, la sensación de que el entorno hiede a excremento la evoca la frase "no llenarse todo" y el narrador, aunque está tratando de esquivar la pobreza y la precariedad, tiene la certeza de que está irremediablemente destinado a morir en medio de ellas. Metafóricamente, este pasaje hace alusión a la caída del excremento, pero en "Lluvia de trópico" de Hernández, el aguacero está conformado, literalmente, de caca de perro.

En el texto, después del aguacero, un decreto oficial le impide a los ciudadanos transitar libremente por la ciudad, con el fin de solucionar lo que los gobernantes llamaron "una enfermedad ambiental"; no obstante, a los ciudadanos no les molestaba el hedor, sino que más bien, "[les] producía una sensación de comodidad muy cercana a lo agradable" (2007b: 70). En consecuencia, cuando el gobierno limpia la caca, los ciudadanos optan por tener perros y ponerlos a defecar en sus casas para "disfrutar" el olor; y otros, aprovechándose de la situación, han hecho criaderos de caca y han empezado a negociar con ellos. Además, expresan su preferencia de vivir en esta inmundicia propensos a su propia destrucción: "por más que suplicamos, el gobierno no ha permitido que vuelva a llover caca de perro" (Hernández: 2007b: 71).

Figurativamente, la lluvia viene a ser una alusión irónica a la reproducción de la caca, ya que es un símbolo de fecundación del suelo donde se obtiene fertilidad y luego la germinación (Silvar y Rodríguez: 1995: 671). Estas interpretaciones sugieren que el entorno excrementicio sea fértil y reproducible. Además, las vivas imágenes olfativas y visuales de la caca remiten a los estados de descomposición y decadencia que, de forma deconstructiva, ilustran las condiciones de vida de la sociedad salvadoreña. La narración deconstruye la idea de estabilidad, comodidad y bienestar al privilegiar como ideal un ambiente degradado y repulsivo. Por esta razón, cuando el gobierno interviene para limpiar el excremento, los ciudadanos prefieren volver a las condiciones insalubres. Desean estar inmersos en condiciones escatológicas. Estas condiciones pueden simbolizar la degradación en la cual los sectores populares excluidos se han acostumbrado pasivamente a vivir. La crítica que sugiere el texto es que muchos subalternos han caído en la indiferencia y la pasividad y se niegan a buscar oportunidades que les permitan salir de su condición de degradación. Además, mediante el uso de la ironía, hay una interpelación al lector de reaccionar ante la repulsión, ante las imágenes 
excrementicias como si el narrador dijera no es posible querer vivir así.

Las imágenes olfativas y visuales de la lluvia así como la carpeta de caca, no solo sugieren la representación figurativa de lo abyecto dentro de un contexto corrupto, infecto y degenerado, sino también podrían remitir simbólicamente a las relaciones de poder. Solo por mencionar algunas de estas relaciones podemos pensar en los constantes ataques a los derechos humanos y civiles que sufrieron y continúan sufriendo los subalternos a lo largo del tiempo, ya que ni los proyectos revolucionarios ni las políticas renovadas después de la guerra han logrado mejorar sus condiciones de existencia, sino que han aumentado la brecha social.

Otra interpretación alude las condiciones excluyentes y marginalizantes generadas por el sistema y reforzadas por el neoliberalismo, ya que la lluvia de caca, podría estar apelando al ambiente de destrucción y explotación de los recursos naturales: la deforestación, la contaminación y obstrucción de aguas, la infertilidad, la degradación del suelo, y la erosión que obligó a los subalternos a vivir en condiciones más precarias que las que ya tenían y que aumentaron la desnutrición, las enfermedades, la pobreza, y eventualmente la mortalidad (Faber: 1992, 10). De allí que los subalternos, acostumbrados a vivir en precariedad, prefieran vivir 'en medio de la caca' para evitar así su desaparición antes que acatar las disposiciones del gobierno, un gobierno que se conoce por crear y desarrollar entornos en donde el excremento constituye parte de modus vivendi. Excremento y gobierno simbolizan la corrupción dentro del sistema de dominación.

\section{Conclusiones}

Para concluir, la asociación de subjetividades a diferentes tipos de animales se vinculan tanto con la hegemonía y los sistemas de poder como con los oprimidos y la subalternidad. No obstante, cabe rescatar que cuando se vincula al subalterno con figuras animalistas, los subalternos siempre aparecen en desventaja.
Además, a diferencia de algunas bestias, ellos son los que muestran el afecto y el amor como una necesidad y un motor que los mueve en la búsqueda y el calor del otro. Las narraciones describen a los oprimidos en la posguerra en desventaja con respecto a otro envestido de poder que no siempre es visiblemente identificado. Pareciera que la intencionalidad discursiva en la narración, más que identificar al poder, es presentar la degradación y el horror de la condición existencial de los grupos oprimidos. En una buena mayoría de casos, el oprimido representado en los relatos es víctima del uso de violencia al interactuar con otros. Es un tipo de violencia que pareciera ser legada por la historia, que se ha ejercido sobre sus cuerpos y mentes y que, pareciera, continuará reproduciéndose.

\section{Notas}

1 Por especies endémicas debe entenderse la creación de personajes que representan subjetividades exclusivas y originales en la obra de Hernández, como por ejemplo, la del hombre buitre, un humano mitad hombre y mitad buitre.

2 Un ejemplo lo constituye el reino de terror impuesto por Osmín Aguirre cuando organiza los llamados Escuadrones de la muerte y las Operaciones limpieza, cuya misión es la de masacrar, torturar e inmovilizar las fuerzas políticas populares y al pueblo en general.

3 Carlos Cabarrúz (1985), citado por Camacho y Menjívar (1985) en Movimientos Populares en Centroamérica, sostiene que los núcleos indígenas que hubo se han disuelto en un total mestizaje y que la herencia indígena fue aniquilada (Camacho, Menjívar: 1985: 346). Añade el antropólogo Alejandro Marroquín (1975) que la mayoría de los salvadoreños todavía se preguntan si existe un problema indígena y manifiestan que, en todo caso, ellos (los indios) son tan pocos y están tan integrados a la vida nacional que no vale la pena hablar de ellos (749). Y por otro, además de la invisibilización, estas comunidades continúan siendo víctimas de discriminación y genocidios (Gallardo: 1993:73).

Las élites cultas formaron parte del "mestizaje interclasista" que se desarrolló en algunos países latinoamericanos y expandió la proliferación de 
los "grupos cultos" mezclados entre la mayoría analfabeta. Estos grupos pretendían controlar el poder excluyendo a enormes sectores de la población (García-Canclini: 1990: 71-72).

Foucault analiza un modelo articulado mediante el cual las prácticas discursivas y sociales objetivizan a los sujetos dentro del sistema penal durante la Edad Media. En este texto se examinan el castigo y la disciplina en cuanto prácticas que afectan las relaciones de poder entre los hombres. En este sentido, Foucault se refiere a las formas en que operaban estas prácticas en diferentes escenarios, subrayando que el poder sobre los hombres se ejerce controlando sus cuerpos, sus relaciones: vigilándolos, inspeccionándolos y disciplinándolos (183). De esta manera, establece relaciones fecundas para el análisis al vincular la relación entre el funcionamiento del poder y el poder disciplinario.

Un ejemplo de estos grupos legitimados lo proveen las clases altas, gobernantes y el Estado cuando, antes de la guerra, crearon "una nueva identidad nacional basada en el anticomunismo" sustentada por un poderoso control político, militar y social a cargo principalmente de las Guardias Cívicas, el ejército, y la Guardia Nacional (Alvarenga: 1996: 326-335) y se avocaron a "desaparecer" y masacrar a los sectores marginados como los indios y campesinos organizados. O pueden también representar a las élites cultas a las que se refería García-Canclini (1990:71), que al crear un orden dominante semi-aristocrático imponen modelos sociales y económicos eurocéntricos para, según ellos, beneficiar a todos por igual pero que solo sirven para privilegiar a las minorías.

Si se entrecruza la trama de este relato con la historia se puede hacer referencia a la brecha social señalando que la polarización social en El Salvador antes de los conflictos bélicos generaba una brecha entre ricos y pobres que señalaba que el $10 \%$ de la población disfrutaba del $80 \%$ de las riquezas del país. Tanto el estado y los militares como las clases oligárquicas en cuyas manos estaba la nación, desarrollaron un estilo de vida cuyas leyes regulaban un código ético al margen de la legalidad - situación que desarrolló un tipo de violencia no institucionalizada pero generalizada en medio de todos los ámbitos en donde el poder generaba conflictividad (Alvarenga: 1996: 141).

Pérez Brignoli (1985) destaca que en El Salvador algunos observadores externos de la insurrección de 1932 revelaron las condiciones que permitieron el surgimiento del comunismo: "los trabajadores rurales eran miserablemente pagados y en muchas fincas soportaban condiciones de trabajo intolerables (...) para el propietario, un animal de granja vale mucho más que un trabajador; tal es la abundancia en la oferta de brazos" (94).

9 Las condiciones descritas por colonizadores como Gonzalo Fernández de Oviedo detallan al contexto como un espacio infecto, plagado de hambre y muerte, caótico por el desgobierno, los levantamientos indígenas desprovistos de facilidades básicas, la corrupción (Fernández de Oviedo: 1950).

\section{Bibliografía}

Alvarenga, Patricia (1996) Cultura y Etica de la Violencia. El Salvador 1880-1932. San José: Ed. EDUCA.

Argueta, Manlio (2008 a) El valle de las hamacas. San Salvador: UCA Editores.

Chevalier, Jean (1995). Diccionario de símbolos de Jean Chevalier. Sivar, Manuel y Arturo Rodríguez, eds. Barcelona: Editorial Herder.

Cortez, Beatriz (2002) La Construcción de la identidad como fuente de violencia y su representación en la literatura Centroamericana de posguerra. Ponencia X2. Congreso Internacional literatura Centroamericana. Instituto Iberoamericano Berlín.

Curvardic, Dorde (2013), asesor tesis: "Subaltenidad, Exclusión y Violencia: La Construcción de Subjetividades en la Obra Literaria de Claudia Hernández". Sesión de defensa de tesis doctoral presentada por la postulante Hilda Gairaud R. San José: Universidad de Costa Rica.

Dalton, Roque (1998). Las historias prohibidas de pulgarcito. Mexico: UCA Editores. 
Dreyfus, H. y P. Rabinov (2001) Michel Foucault, más allá del estructuralismo y la hermenéutica. Buenos Aires: Nueva Visión Argentina.

Dreyfus, H. y P. Rabinov. (2005) Olvida Uno. San Salvador: Índole Editores.

Dreyfus, H. y P. Rabinov. (2007b) De Fronteras. Guatemala: Piedra Santa

Dreyfus, H. y P. Rabinov. (2007c) La canción del mar. (obra inédita)

Mackenbach, Werner (2011). “De la politización a la esteticización? Transformaciones de la violencia y sus representaciones en América Latina". Conferencia impartida en el Simposio "Discursos de violencia y goce en América Latina". Universidad de Costa Rica, 19-20 de setiembre de 2011 (inédita).
Pérez Brignoli, Héctor (1985). Breve Historia de Centroamérica. Madrid: Alianza Editorial S.A.

Pérez, Yensi (2012) "El poder de la abyección y la ficción de posguerra". En Perversiones de la modernidad. Literaturas, identidades y desplazamientos III Guatemala: F\&G Editores

Solís, Luis G. e Isayana Baldizón (1999). La integración regional y los desafíos de sus relaciones externas. Centroamérica 2020. Hamburg: Institut für IberoamerikaKunde 2000. http://www.giga-berlin.de/ content/ilas/ze2020/solis.pdf

Taylor, Charles. (1996). Las fuentes del yo. La construcción de la identidad moderna. México: Paidos.

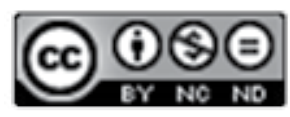

Este obra está bajo una licencia de Creative Commons Reconocimiento-NoComercial-SinObraDerivada 4.0 Internacional. 
